\section{Relative Susceptibility of Selected Apple Cultivars to Botryosphaeria dothidea}

\author{
Alan R. Biggs ${ }^{1}$ \\ West Virginia University, Kearneysville Tree Fruit Research and Education \\ Center, P.O. Box 609, Kearneysville, WV 25430
}

Stephen S. Miller ${ }^{2}$

USDA-ARS, Appalachian Fruit Research Station, 45 Wiltshire Road, Kearneysville, WV 25430

Additional index words. Malus $\times$ domestica, white rot, bot rot, cultivar evaluation, disease susceptibility

\begin{abstract}
Twenty-three apple (Malus $\times$ domestica Borkh.) cultivars were tested in the field and laboratory for their relative susceptibility to the white rot pathogen, Botryosphaeria dothidea. Wounded fruit were inoculated in the field at 2 to 3 weeks preharvest with mycelium from 14- to 21-day-old cultures. In the laboratory, detached fruit were similarly inoculated. Fruit were rated for relative susceptibility to the fungus with two criteria: disease severity of attached fruit in the field based on lesion growth ( $\mathrm{mm} /$ degree-day) and disease severity of detached fruit in laboratory inoculations of wounded fruit (mean lesion diameter after 5 days). Based on the laboratory and field data from 2 years of study, cultivars were classified into three relative susceptibility groups: most susceptible: 'Fortune' and 'Pristine'; moderately susceptible: 'Golden Supreme', 'Creston', 'Ginger Gold', ‘Sansa', ‘Golden Delicious', ‘Senshu’, ‘Orin', ‘Sunrise', ‘GoldRush', ‘Arlet', 'Braeburn', 'Cameo', 'Enterprise', 'Fuji', 'Shizuka', 'Gala Supreme', and NY 75414; and least susceptible: 'Honeycrisp', 'Yataka', 'Suncrisp', and 'PioneerMac'. Compared to previous cultivar rankings, the results of the present study indicate that some new apple cultivars from the first NE-183 planting show greater resistance to Botryosphaeria dothidea than current standard cultivars.
\end{abstract}

White rot, or bot rot, caused by the fungus Botryosphaeria dothidea (Moug.) Ces. \& De Not., is an important disease in the mid-Atlantic and southeastern United States (Jones and Aldwinckle, 1990). Disease outbreaks can occur rapidly and losses can be severe, especially under prolonged warm, wet weather conditions (Jones and Aldwinckle, 1990). Field evaluations for the incidence of rot diseases in apple can be difficult because of the similarity of symptoms caused by the various pathogens (e.g., Colletotrichum acutatum, C. gloeosporioides, Botryosphaeria dothidea, B. obtusa). Determination of the causal organisms from natural infections by isolation is labor-intensive and may yield multiple rot pathogens and contaminating organisms. Laboratory and/or field inoculation studies under controlled conditions eliminate problems with uneven distribution of inoculum and the difficulty in the field of being certain that differences in resistance are real or due to inoculum escape. In addition, controlled studies provide the opportunity for positive identification of symptoms and characterization of the host pathogen relationship. The susceptibility ranking of various apple cultivars to diseases often depends on the plant breeder and

Received for publication 3 Apr. 2002. Accepted for publication 1 July 2002. Appreciation is extended to Larry Crim and Robert Young for technical assistance.

${ }^{1}$ Professor. To whom requests for reprints should be addressed.

${ }^{2}$ Research Horticulturist. a few test sites or on observations by growers, nursery personnel, or both, in the field rather than the results of systematic study. In 1994, a regional project was initiated to examine the performance of new apple cultivars in replicated trials under a wide range of climatic and edaphic conditions. The project (NE-183), entitled "Multidisciplinary Evaluation of New Apple Cultivars", has 26 cooperators in 18 states and two Canadian provinces. A primary objective of the NE-183 project is to evaluate horticultural qualities and pest susceptibility of new apple cultivars, strains, and advanced selections with commercial potential and to determine the limitations and positive attributes of these cultivars. To date, researchers have documented the relative susceptibilities of the NE-183 apple cultivars to apple scab (caused by Venturia inaequalis), powdery mildew (caused by Podosphaera leucotricha), cedar apple rust (caused by Gymnosporangium juniperi-virginianae), and bitter rot (caused by Colletotrichum acutatum) (Biggs and Miller, 2001; Jones et al., 1998; Kiyomoto et al., 1998; Rosenberger et al., 1996; Yoder et al., 1997). The objective of this study was to evaluate the relative susceptibility of apple cultivars to the white rot pathogen, $B$. dothidea.

\section{Materials and Methods}

Test planting. The 23 apple cultivars selected for the NE-183 project were budded on M.9337 rootstock. Trees were planted in north- south oriented rows in Apr. 1995 at a spacing of $2.5 \times 4.3 \mathrm{~m}$ using a mechanical tree planter. The design was a randomized complete block with five single-tree plots per cultivar. Drive middles were planted with Kentucky-31 fescue (Festuca arundinacea), and a weed-free strip ( $1 \mathrm{~m}$ wide in $1995 ; 2 \mathrm{~m}$ wide in the remaining years) was maintained in the tree row using paraquat plus oryzalin at recommended rates (Pfeifer et al., 1995). After planting, a conduit stake secured to a single trellis wire at $2.1 \mathrm{~m}$ height was placed beside each tree and the tree's leader was tied to the stake. Minimal pruning was followed throughout this study allowing trees to assume their natural form. Blossoms were removed in the first season (1995). Trees were allowed to fruit after the first growing season and crop load was adjusted by hand to space fruit $\approx 15 \mathrm{~cm}$ apart. Drip irrigation was installed in summer 1997. The planting received no pesticide applications in 1995. Insecticides were applied from 1996 through 2000, as were fixed copper and streptomycin to suppress fire blight. Dodine, myclobutanil, fenarimol, and/or mancozeb were applied at recommended rates (Pfeifer, 1995) beginning 12 Apr., and continuing through 21 May 2001, for early season scab control. No fungicides were applied after 21 May in 2000 or 2001. Twenty-three cultivars (Table 1) were selected in the planting for field inoculation tests in 2000 and 2001. Temperature, relative humidity and leaf wetness were monitored with a 7-d recorder (Belfort Instruments, Baltimore, Md.).

Fungal isolates. Botryosphaeria dothidea is the predominant apple rot pathogen in the mid-Atlantic region. Based on preliminary experiments with a collection of isolates, a representative fungal isolate [designated BdPA-1, obtained from Dr. K.D. Hickey (Pennsylvania State Univ., Tree Fruit Research and Extension Center, Biglerville, Pa.)] was selected, and subcultured and maintained on potato dextrose agar in petri dishes. Fungus cultures were subcultured biweekly and maintained at $22{ }^{\circ} \mathrm{C}$ under continuous fluorescent light during the periods in which experiments were conducted.

Field experiments. Fruit were inoculated in the field at 2 to 3 weeks preharvest (Table 1 ), as determined by average ripening date and quality assessments, which included starch index rating, soluble solids concentration (SSC), and flesh firmness. Arbitrarily selected fruit were inoculated by making a 1-mm-deep wound through the fruit epidermis with a sterile 5-mm-diameter cork borer, removing the circumscribed epidermis and placing a 5-mm-diameter agar plug supporting fungus mycelium over the wound. Wounds were wrapped in Parafilm to maintain moist conditions. The Parafilm was removed after $5 \mathrm{~d}$. Twenty-four fruit were inoculated per cultivar in three replications of eight fruit, and eight fruit were inoculated with sterile agar as a control. None of the control fruit developed white rot during the course of the study. The study was conducted in 2000 and 2001.

Laboratory experiments. Fruit were picked at 2 to 3 weeks before their normal harvest date, brought to the laboratory, and washed with 
Table 1. Cultivar, date of inoculation, soluble solids, fruit firmness, and mean temperature for the 5-d period following inoculation for apple cultivars inoculated with Botryosphaeria dothidea.

\begin{tabular}{|c|c|c|c|c|c|c|c|c|}
\hline \multirow[b]{2}{*}{ Cultivar } & \multicolumn{4}{|c|}{2000} & \multicolumn{4}{|c|}{2001} \\
\hline & $\begin{array}{l}\text { Inoculation } \\
\text { date }\end{array}$ & $\begin{array}{l}\text { Soluble solids } \\
(\%)^{\mathrm{z}}\end{array}$ & $\begin{array}{l}\text { Fruit firmness } \\
\qquad(\mathrm{Kg})^{\mathrm{z}}\end{array}$ & $\begin{array}{l}\text { Mean temp } \\
\left({ }^{\circ} \mathrm{C}\right)\end{array}$ & $\begin{array}{l}\text { Inoculation } \\
\text { date }\end{array}$ & $\begin{array}{l}\text { Soluble solids } \\
(\%)^{\mathrm{z}}\end{array}$ & $\begin{array}{l}\text { Fruit firmness } \\
\qquad(\mathrm{Kg})^{\mathrm{z}}\end{array}$ & $\begin{array}{c}\text { Mean temperature } \\
\left({ }^{\circ} \mathrm{C}\right)\end{array}$ \\
\hline Pristine & 13 July & 14.2 & 7.1 & 20.2 & 11 July & 10.4 & 8.6 & 19.9 \\
\hline Sunrise & 17 July & 12.8 & 8.8 & 20.1 & 12 July & 11.3 & 10.0 & 19.9 \\
\hline Sansa & 26 July & 13.2 & 8.2 & 21.2 & 25 July & 12.1 & 7.8 & 20.8 \\
\hline Ginger Gold & 27 July & 14.0 & 10.3 & 21.2 & 2 Aug. & 12.8 & 8.2 & 23.7 \\
\hline PioneerMac & $--y^{y}$ & --- & --- & --- & 10 Aug. & 12.6 & 9.9 & 23.4 \\
\hline Arlet & 1 Aug. & 13.2 & 10.0 & 22.1 & 9 Aug. & 13.4 & 8.2 & 24.6 \\
\hline Senshu & 9 Aug. & 14.2 & 8.9 & 21.6 & 9 Aug. & 12.0 & 9.8 & 24.6 \\
\hline Golden Supreme & 14 Aug. & 13.1 & 8.8 & 20.3 & 15 Aug. & 12.5 & 8.2 & 22.4 \\
\hline Honeycrisp & 15 Aug. & 14.5 & 8.2 & 19.8 & 10 Aug. & 12.7 & 9.6 & 23.4 \\
\hline Creston & 28 Aug. & 14.1 & 7.7 & 22.1 & 31 Aug. & 14.0 & 7.3 & 20.4 \\
\hline Fortune & 28 Aug. & 13.0 & 8.4 & 22.1 & 5 Sept. & 14.3 & 7.4 & 20.0 \\
\hline NY75414 & 29 Aug. & 13.2 & 7.5 & 22.8 & 30 Aug. & 12.4 & 8.5 & 20.6 \\
\hline Golden Delicious & 30 Aug. & 13.0 & 8.1 & 23.3 & 5 Sept. & 13.4 & 8.4 & 20.0 \\
\hline Gala Supreme & 5 Sept. & 15.6 & 8.5 & 16.5 & 12 Sept. & 14.1 & 8.9 & 15.4 \\
\hline Shizuka & 5 Sept. & 15.7 & 6.2 & 16.5 & 6 Sept. & 14.5 & 7.1 & 20.7 \\
\hline Orin & 13 Sept. & 15.5 & 8.3 & 16.3 & 12 Sept. & 13.8 & 8.5 & 15.4 \\
\hline Yataka & 13 Sept. & 18.1 & 7.4 & 16.3 & 6 Sept. & --- & --- & 20.7 \\
\hline Braeburn & 14 Sept. & 13.3 & 9.7 & 15.3 & 20 Sept. & 12.2 & 9.8 & 18.9 \\
\hline Cameo & 14 Sept. & 13.7 & 7.7 & 15.3 & 19 Sept. & 13.2 & 8.0 & 19.0 \\
\hline Fuji & 18 Sept. & 11.5 & 8.2 & 16.6 & 19 Sept. & 14.0 & 8.4 & 19.0 \\
\hline Suncrisp & 20 Sept. & 15.6 & 9.2 & 18.3 & 27 Sept. & 14.9 & 8.3 & 11.3 \\
\hline Enterprise & 20 Sept. & 13.0 & 7.1 & 18.3 & 21 Sept. & 8.0 & 14.2 & 17.8 \\
\hline GoldRush & 5 Oct. & 14.6 & 10.0 & 10.3 & 3 Oct. & 14.2 & 8.2 & 16.8 \\
\hline
\end{tabular}

${ }^{\mathrm{z}}$ Measurements are the means from five fruit arbitrarily selected and measured on the inoculation date.

${ }^{y}$ Not inoculated in 2000.

tap water. Fruit were inoculated as described above, placed in plastic trays with lids, and incubated at 21 to $23{ }^{\circ} \mathrm{C}$ in the laboratory. Thirty-two fruit, including three replications of eight fruit, and eight fruit inoculated with sterile agar were used. None of the control fruit developed white rot during the observation period. Five additional fruit of each cultivar were sampled for determination of flesh firmness and SSC. Flesh firmness was measured with a hand-held penetrometer (Effigi, Bologna, Italy) fitted with an 11-mm tip. Soluble solids were measured with a hand-held refractometer (Fisher Scientific, Pittsburgh). The study was conducted over two growing seasons, 2000 and 2001.

Data collection and analysis. Fruit were rated for relative susceptibility to the fungus using two criteria: disease severity of attached fruit in the field and disease severity of detached fruit in laboratory inoculations of wounded fruit. Severity was obtained from the mean of two measurements (length and width) from each lesion. Only symptomatic fruit were included in the calculation of mean wound severity. In both studies, severity was determined at 5 and $8 \mathrm{~d}$ postinoculation, but many lesions were too large to measure after $8 \mathrm{~d}$, so only the 5-d measurements were analyzed. Field severity data were adjusted for temperature by calculating lesion diameter increase per degree-day accumulation (base temperature $=$ $\left.0{ }^{\circ} \mathrm{C}\right)$. Cultivar ranks from the two tests over two growing seasons were used to calculate the mean relative susceptibility rating. Mean lesion diameter data were subjected to analysis of variance and means were separated with the Waller-Duncan k-ratio $t$ test (SAS Institute, Cary, N.C.). Final cultivar ranks were determined by averaging the mean ranks for the four sets (field and laboratory severity from each of the two years' experiments) of observations.
The nonparametric Spearman rank correlation analysis was used to determine the relationships among the various measures and with harvest date, fruit firmness, and SSC.

\section{Results and Discussion}

Field experiments. White rot incidence following inoculations with mycelium in 2000 and 2001 was $99 \%$. In 2000, severity ranged from $0.23 \mathrm{~mm}$ lesion increase/degree-day for 'Pristine' to $0.08 \mathrm{~mm}$ lesion increase/degreeday for 'Yataka' (Table 2). In 2001, severity ranged from $0.27 \mathrm{~mm}$ lesion increase/degreeday for 'Golden Delicious' and 'Fortune' to $0.12 \mathrm{~mm}$ lesion increase/degree-day for 'PioneerMac' (Table 2). 'PioneerMac', 'Yataka', and 'Enterprise' had the highest mean ranks (least susceptible) for field severity, whereas 'Fortune', 'Pristine', and 'GoldRush' had the lowest mean ranks (most susceptible) (Table $3)$. The cultivar $\times$ year interaction was significant, with some cultivars showing significant differences between years (i.e., most notable 'Ginger Gold', 'Suncrisp', 'Golden Supreme', and 'Sansa').

Temperatures in the field might have contributed to the variability of the field experiments between years; 2000 was $\approx 1^{\circ} \mathrm{C}$ cooler than 2001 (Table 1), although some cultivars were exposed to differing postinoculation temperatures in each year (i.e., some cultivars were exposed to warmer temperatures in 2000 and others exposed to warmer temperatures in 2001). 'Suncrisp' was the most extreme example with a $7{ }^{\circ} \mathrm{C}$ difference between years (Table 1). Mean daily temperatures in 2000 ranged from 10.3 to $23.3{ }^{\circ} \mathrm{C}$, compared to 2001 when temperatures ranged from 11.3 to $24.6{ }^{\circ} \mathrm{C}$ (Table 1). Although lesion growth in the field was calculated as a function of temperature, it is possible that pre-inoculation temperature conditions or other environmental variables may have contributed to the observed cultivar $\times$ year variation in susceptibility to B. dothidea.

Laboratory experiments. White rot incidence following inoculations with mycelium in 2000 and 2001 was $98 \%$. In 2000 , severity ranged from $48.4 \mathrm{~mm}$ for 'Pristine' to $11.7 \mathrm{~mm}$ for the apple scab resistant cultivar 'GoldRush' (Table 2). In 2001, severity ranged from 35.9 $\mathrm{mm}$ for 'Ginger Gold' to $16.8 \mathrm{~mm}$ for 'Suncrisp'. 'Pristine' had the lowest mean rank (most susceptible) for severity, followed by 'Fortune', whereas 'Yataka', 'Honeycrisp', and 'Shizuka' appeared most resistant based on the mean ranks of the laboratory tests (Table $3)$. There was a significant cultivar $\times$ year interaction for severity in the laboratory, with some cultivars showing significant differences between years. The cultivars that showed the most variation between years included those mentioned above as showing the most variation between years in the field tests, i.e., 'Ginger Gold', 'Suncrisp', 'Golden Supreme', and 'Sansa', and in addition, 'Orin'.

Fruit firmness and percent soluble solids were negatively correlated, with apples measuring less firm generally having higher soluble solids $(r=-0.64, P=0.001)$. Date of harvest was positively correlated with soluble solids $(r=0.49, P=0.02)$, but not with firmness $\left(r_{s}^{s}=-0.14, P=0.51\right)$. Cultivars that matured later generally tended to possess increased soluble solids. Also, cultivars that matured later tended to have smaller lesions and appeared more resistant to $B$. dothidea $(r=0.40, P=$ $0.05)$. Disease severity in the laboratory was negatively correlated with soluble solids, but not with firmness $(r=-0.47, P=0.02$, and $r$ s $=0.06, P=0.78$, respectively) with fruit possessing lower soluble solids tending to develop larger lesions. In contrast, disease severity in 
Table 2. Disease severity on selected apple cultivars inoculated in the field and laboratory with Botryosphaeria dothidea in 2000 and 2001.

\begin{tabular}{|c|c|c|c|c|c|c|}
\hline \multirow[b]{2}{*}{ Cultivar } & \multicolumn{2}{|c|}{$\begin{array}{c}\text { Harvest date } \\
\operatorname{rank}^{\mathrm{z}} \\
\end{array}$} & \multicolumn{2}{|c|}{$\begin{array}{c}\text { Field severity rating } \\
(\mathrm{mm} \text { lesion increase/degree-day })^{\mathrm{y}}\end{array}$} & \multicolumn{2}{|c|}{$\begin{array}{l}\text { Laboratory severity rating } \\
\text { [lesion diam }(\mathrm{mm}) \text { after } 5 \mathrm{~d}]^{y}\end{array}$} \\
\hline & 2000 & 2001 & 2000 & 2001 & 2000 & 2001 \\
\hline Fortune & 13 & 13 & $0.17 b^{x}$ & $0.27 \mathrm{a}$ & $29.8 \mathrm{c}$ & $33.6 \mathrm{ab}$ \\
\hline Pristine & 1 & 1 & $0.23 \mathrm{a}$ & $0.24 \mathrm{~b}$ & $48.4 \mathrm{a}$ & $32.0 \mathrm{a}-\mathrm{c}$ \\
\hline Golden Supreme & 7 & 9 & $0.10 \mathrm{i}-\mathrm{k}$ & $0.26 \mathrm{a}$ & $35.3 \mathrm{~b}$ & $22.5 \mathrm{f}-\mathrm{i}$ \\
\hline Creston & 12 & 11 & $0.16 \mathrm{~cd}$ & $0.19 \mathrm{f}-\mathrm{h}$ & $22.8 \mathrm{ef}$ & $25.9 \mathrm{~d}-\mathrm{f}$ \\
\hline Ginger Gold & 4 & 4 & $0.16 \mathrm{bc}$ & $0.14 \mathrm{i}$ & $19.1 \mathrm{~g}$ & $35.9 \mathrm{a}$ \\
\hline Sansa & 3 & 3 & $0.22 \mathrm{a}$ & $0.19 \mathrm{gh}$ & $26.4 \mathrm{~cd}$ & $21.4 \mathrm{f}-\mathrm{j}$ \\
\hline Golden Delicious & 10 & 12 & $0.10 \mathrm{i}$ & $0.27 \mathrm{a}$ & $15.0 \mathrm{ij}$ & $25.4 \mathrm{~d}-\mathrm{f}$ \\
\hline Senshu & 8 & 6 & $0.14 \mathrm{f}-\mathrm{h}$ & $0.19 \mathrm{f}-\mathrm{h}$ & $23.4 \mathrm{~d}-\mathrm{f}$ & $22.3 \mathrm{f}-\mathrm{i}$ \\
\hline Orin & 16 & 17 & $0.10 \mathrm{ij}$ & $0.22 \mathrm{c}-\mathrm{e}$ & $15.3 \mathrm{~h}-\mathrm{j}$ & $34.1 \mathrm{a}$ \\
\hline Sunrise & 2 & 2 & $0.12 \mathrm{gh}$ & $0.20 \mathrm{e}-\mathrm{g}$ & $19.2 \mathrm{~g}$ & $27.9 \mathrm{c}-\mathrm{e}$ \\
\hline GoldRush & 23 & 23 & $0.15 \mathrm{c}-\mathrm{e}$ & $0.23 \mathrm{bc}$ & $11.7 \mathrm{j}$ & $23.4 \mathrm{e}-\mathrm{h}$ \\
\hline Arlet & 6 & 5 & $0.14 \mathrm{e}-\mathrm{g}$ & $0.14 \mathrm{i}$ & $23.8 \mathrm{de}$ & $22.5 \mathrm{f}-\mathrm{i}$ \\
\hline Braeburn & 21 & 20 & $0.13 \mathrm{f}-\mathrm{h}$ & $0.17 \mathrm{~h}$ & $20.8 \mathrm{e}-\mathrm{g}$ & $27.3 \mathrm{de}$ \\
\hline Cameo & 18 & 18 & $0.10 \mathrm{i}$ & $0.22 \mathrm{c}-\mathrm{e}$ & $20.2 \mathrm{fg}$ & $24.8 \mathrm{~d}-\mathrm{g}$ \\
\hline Enterprise & 22 & 21 & $0.10 \mathrm{i}-\mathrm{k}$ & $0.17 \mathrm{~h}$ & $23.3 \mathrm{~d}-\mathrm{f}$ & $29.4 b-d$ \\
\hline Fuji, B.C. No. 2 & 20 & 19 & $0.09 \mathrm{j}-1$ & $0.22 \mathrm{c}-\mathrm{e}$ & $18.1 \mathrm{~g}-\mathrm{i}$ & $27.9 \mathrm{c}-\mathrm{e}$ \\
\hline Shizuka & 15 & 14 & $0.14 \mathrm{~d}-\mathrm{f}$ & $0.22 \mathrm{~b}-\mathrm{d}$ & $14.1 \mathrm{j}$ & $21.3 \mathrm{f}-\mathrm{j}$ \\
\hline Gala Supreme & 14 & 16 & $0.12 \mathrm{~h}$ & $0.24 \mathrm{bc}$ & $18.6 \mathrm{gh}$ & $19.9 \mathrm{~h}-\mathrm{j}$ \\
\hline NY75414-1 & 11 & 10 & $0.12 \mathrm{gh}$ & $0.13 \mathrm{i}$ & $24.3 \mathrm{de}$ & $19.7 \mathrm{~h}-\mathrm{j}$ \\
\hline Honeycrisp & 9 & 8 & $0.10 \mathrm{i}$ & $0.21 \mathrm{~d}-\mathrm{f}$ & $---{ }^{\mathrm{w}}$ & $20.2 \mathrm{~g}-\mathrm{j}$ \\
\hline PioneerMac & 5 & 7 & $---{ }^{w}$ & $0.12 \mathrm{i}$ & $---\mathrm{w}$ & $21.5 \mathrm{f}-\mathrm{i}$ \\
\hline Suncrisp & 19 & 22 & $0.08 \mathrm{kl}$ & $0.26 \mathrm{a}$ & $21.7 \mathrm{e}-\mathrm{g}$ & $16.8 \mathrm{j}$ \\
\hline Yataka & 17 & 15 & 0.081 & $0.19 \mathrm{gh}$ & $12.7 \mathrm{j}$ & $18.2 \mathrm{ij}$ \\
\hline
\end{tabular}

${ }^{\mathrm{z}}$ Harvest date rank is from earliest $=1$ to latest $=23$. Cultivars are arranged from most susceptible to least susceptible based on the combined mean ranks from laboratory and field tests.

${ }^{\mathrm{y}}$ Field and laboratory severity data are from $5 \mathrm{~d}$ postinoculation for both years.

${ }^{x}$ Data are the mean of 24 observations from three replicates of eight fruit per replicate. Different letters denote significant differences among means according to the Waller-Duncan test $(P \leq 0.05)$.

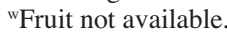

Table 3. Mean ranks for field and laboratory disease severity of selected apple cultivars inoculated with Botryosphaeria dothidea in 2000 and 2001, listed from most to least susceptible based on combined mean ranks

\begin{tabular}{lcccc}
\hline Cultivar & $\begin{array}{c}\text { Mean harvest } \\
\text { date rank }^{z}\end{array}$ & $\begin{array}{c}\text { Mean laboratory } \\
\text { severity rank }\end{array}$ & $\begin{array}{c}\text { Mean field } \\
\text { severity rank }\end{array}$ & $\begin{array}{c}\text { Combined } \\
\text { mean rank }\end{array}$ \\
\hline Fortune & 13 & $3.0^{y}$ & $2.0^{y}$ & $2.5^{\mathrm{x}}$ \\
Pristine & 1 & 2.5 & 3.0 & 2.75 \\
Golden Supreme & 8 & 8.0 & 10.5 & 9.25 \\
Creston & 11.5 & 9.0 & 10.0 & 9.5 \\
Ginger Gold & 4 & 7.5 & 12.5 & 10.0 \\
Sansa & 3 & 10.5 & 9.5 & 10.0 \\
Golden Delicious & 11 & 14.0 & 8.0 & 11.0 \\
Senshu & 7 & 11.0 & 11.5 & 11.25 \\
Orin & 16.5 & 9.5 & 13.0 & 11.25 \\
Sunrise & 2 & 10.0 & 12.5 & 11.25 \\
GoldRush & 23 & 16.5 & 6.5 & 11.5 \\
Arlet & 5.5 & 9.5 & 14.0 & 11.75 \\
Braeburn & 20.5 & 9.5 & 14.5 & 12.0 \\
Cameo & 18 & 11.5 & 13.0 & 12.25 \\
Enterprise & 21.5 & 6.5 & 18.5 & 12.5 \\
Fuji, B.C. No. & 19.5 & 11.0 & 15.0 & 13.0 \\
Shizuka & 14.5 & 18.5 & 7.5 & 13.0 \\
Gala Supreme & 15 & 17.5 & 9.5 & 13.5 \\
NY75414-1 & 10.5 & 13.0 & 16.5 & 14.75 \\
Honeycrisp & 8.5 & 19.0 & 14.0 & 16.5 \\
PioneerMac & 6 & 16.0 & 23.0 & 19.5 \\
Suncrisp & 20.5 & 16.5 & 12.5 & 19.5 \\
Yataka & 16 & 21.0 & 19.0 & 20.0 \\
\hline
\end{tabular}

${ }^{2}$ Harvest date rank is from earliest $=1$ to latest $=23$. Cultivars are arranged from most susceptible $=1$ to least susceptible $=23$ based on the combined mean ranks of field and laboratory tests with wounded fruit.

${ }^{y}$ Data are the mean ranks from experiments conducted in 2000 and 2001. A lower rank indicates higher levels of disease severity.

${ }^{x}$ Data are the combined mean ranks from field and laboratory experiments conducted in 2000 and 2001. A lower rank indicates higher levels of disease severity. the field was negatively correlated with fruit firmness, but not with percent soluble solids $\left(r_{s}=-0.43, P=0.04\right.$, and $r_{s}=0.19, P=0.39$, respectively), with less firm fruit tending to show increased disease severity.

Internal maturity-related changes have been proposed as determining the onset of susceptibility to rot pathogens (Sitterly and Shay, 1960). Cultivar variation in maturity-related changes may be related to cultivar relative susceptibility to rot pathogens. Increased sugar content has been associated with increased susceptibility of apple to white rot caused by $B$. dothidea (Kohn and Hendrix, 1983), with "active rot lesions" seldom occurring until soluble solids reach $10.5 \%$. Brown (1984) provided evidence that linear rot expansion of several apple fruit rotting pathogens was inversely related to levels of endopolygalacturonase inhibitor activity in fruit tissue. Latent infections occur on apple in the early or middle part of the growing season, with infection occurring whenever environmental conditions are favorable (Parker and Sutton, 1993; Biggs, 1995). B. dothidea has a long incubation period in immature and mature fruit (Parker and Sutton, 1993), and symptom expression, rather than susceptibility, may be related to the physiological changes in the fruit, one component of which is the increase in soluble solids.

Other factors may influence the relative susceptibility of apple cultivars to the white rot pathogen. For example, differences in amounts of inoculum from mummies, twig and branch cankers or dead shoots could be an important element of perceived susceptibility in the orchard. Insect feeding preferences among cultivars also could influence perceived susceptibility by creating potential infection courts. Also, early-maturing cultivars could escape the larger amounts of inoculum that occur later in the growing season. Only one isolate of $B$. dothidea was used for the inoculation tests in the present study. Field populations of the fungus vary in virulence (Parker and Sutton, 1993; Jones and Sutton, 1996; Brown-Rytlewski and McManus, 2000), however, cultivar specificity on apple has not been reported.

Based on the combined laboratory and field data from 2 years of study, we classified the cultivars into three relative susceptibility groups: most susceptible: 'Fortune' and 'Pristine'; moderately susceptible: 'Golden Supreme', 'Creston', 'Ginger Gold', 'Sansa', 'Golden Delicious', 'Senshu', 'Orin', 'Sunrise', 'GoldRush', 'Arlet', 'Braeburn', 'Cameo', 'Enterprise', 'Fuj'i, 'Shizuka', 'Gala Supreme', and NY 75414; and least susceptible: 'Honeycrisp', 'Yataka', 'Suncrisp' and 'PioneerMac'. The rankings may be tentative for some of the cultivars showing variation between years in the field and laboratory tests (i.e. 'Ginger Gold', 'Suncrisp', 'Golden Supreme', 'Sansa', and 'Orin'), and additional data may be needed to classify more accurately their relative susceptibility to $B$. dothidea. Previous published rankings have included 'Golden Delicious' among the most susceptible cultivars to the white rot pathogen (McVay et al, 1993). Although McVay etal. based their cultivar rank- 
ings on field observations, their observations and the results of the present study indicate that some new apple cultivars from the first NE-183 planting possess greater resistance to $B$. dothidea than some current standard apple cultivars.

\section{Literature Cited}

Biggs, A.R. 1995. Detecting latent infection in apple fruit with paraquat. Plant Dis. 79: 1062-1067.

Biggs, A.R. and S.S. Miller. 2001. Relative susceptibility of selected apple cultivars to Colletotrichum acutatum. Plant Dis. 85:657-660.

Brown, A.E. 1984. Relationship of endopolygalacturonase inhibitor activity to the rate of fungal rot development in apple fruits. Phytopathol. Z. 111:122-132.

Brown-Rytlewski, D.E. and P.S. McManus. 2000 Virulence of Botryosphaeria dothidea and Botryosphaeria obtusa on apple and management of stem cankers with fungicides. Plant Dis. 84: 1031-1037.
Jones, A.L. and H.S. Aldwinckle. 1990. Compendium of apple and pear diseases. APS Press, St. Paul, Minn.

Jones, A.L., A.R. Biggs, R.K. Kiyomoto, R. McNew, D.A Rosenberger, and K.S. Yoder. 1998. Susceptibility of apple cultivars in the NE-183 project trial to apple scab, 1997. Biological and Cultural Tests for Control of Plant Diseases 13:35.

Jones, A.L. and T.B. Sutton,. 1996. Diseases of Tree Fruits in the East. Mich. Agr. Expt. Sta. Publ. NCR-45.

Kiyomoto, R.K.,AR. Biggs, R. McNew, D.A. Rosenberger, and K.S. Yoder. 1998. Foliage susceptibility of 23 apple cultivars in the NE-183 project trial to cedar-apple rust, powdery mildew, and leaf spots, 1997. Biological and Cultural Tests for the Control of Plant Diseases 13:36.

Kohn, F.C. and F.F. Hendrix. 1983. Influence of sugar content and $\mathrm{pH}$ on development of white rot on apples. Plant Dis. 67:410-412.

McVay, J.R., J.F. Walgenbach, E.J. Sikora, and T.B. Sutton 1993. A grower's guide to apple insects and diseases in the Southeast. Alabama Coop. Ext. Serv. Auburn Univ. Circ. ANR-838.

Parker, K.C. and T.B. Sutton. 1993. Susceptibility of apple fruit to Botryosphaeria dothidea and isolate variation. Plant Dis. 77:385-389.
Pfeifer, D.G. 1995. Virginia, West Virginia, Maryland commercial tree fruit spray bulletin. Virginia Coop. Ext. Serv. Publication 456-419.

Rosenberger, D. A., K.S. Yoder, A.R. Biggs, R.K. Kiyomoto, and R. McNew. 1996. Comparative susceptibility of 23 apple cultivars in the NE-183 trial to powdery mildew and cedar apple rust, 1995. Biological and Cultural Tests for Control of Plant Diseases 11:36.

Sitterly, W.R., and J.R. Shay. 1960. Physiological factors affecting the onset of susceptibility of apple fruit to rotting by fungus pathogens. Phytopathology 50:91-93.

Yoder, K.S., A.R. Biggs, R.K. Kiyomoto, R. McNew, and. D.A. Rosenberger. 1997. Foliage susceptibility of 23 apple cultivars in the NE-183 trial to scab, powdery mildew, cedar apple rust, and leaf spot, 1996. Biological and Cultural Tests for Control of Plant Diseases 12: 42-43. 